\title{
Anticoagulant Activities of Olea Europaea Leaves and Fruit Extract
}

\author{
Himour Sara \\ Laboratory Science Natural and Materials. \\ University Centre Abdelhafid Boussouf. Mila. \\ Belhain Hayat \\ Bouketta Mehbouba \\ University Centre Abdelhafid Boussouf. Mila.
}

Doi: 10.19044/esj.2017.v13n30p90 URL:http://dx.doi.org/10.19044/esj.2017.v13n30p90

\begin{abstract}
The objective of this study is the evaluation of the anticoagulant activity of polyphenols obtained from extracts of the leaves, and fruits of olive (Olea europaea L.) of four varieties cultivated in the station Maazouzi Lakhdar (Mila, Algeria). The anticoagulant activity of the polyphenolic extracts, of the leaves and fruits of olive have been evaluated in vitro, using the test of Quick time (QT). The values of clotting time a showed a surprising anticoagulant activity on the exogenous pathway of coagulation, significant in the case of leaves and fruits of the Chemlel variety.
\end{abstract}

Keywords: Olea europaea L., polyphenols, anticoagulant activity

\section{Introduction}

The olive tree (Olea europaea L.), is one of the major trees that is used since antiquity as an aromatic and medicinal plant and considered as a reservoir of natural compounds of high therapeutic value.

Several epidemiological studies have shown the relationship between the consumption of olive and olive oil, and the low incidence of cardiovascular diseases. In reality, the olive through its products, table olives and olive oil, has a more preventive use than a one because it represents a large part of the Mediterranean diet. The components/parts used in traditional medicine are the leaves and fruits (Bruneton, 1999).

In herbal medicine, the effect of many medicinal plants is assigned in whole or in part to the phenolic compounds of these plants. These substances have a wide range of biological in vitro activities, which make them beneficial to human health such as the antithrombotic effect, antiplatelet 
agent, anti-inflammatory, vasodilator and hypotensive effects therefore (Boskou, 2009).

In addition, the cardiovascular diseases are the first cause of mortality in the world, with a number of deaths which will rise from 17.1 million in 2004 to 23.4 million in 2030 (WHO, 2008).

On the other hand, the lack of essential drugs, the lack of health care, the high cost of drugs and the search for drugs with a minimum of secondary effects explain the recourse to traditional practices based on medicinal plants. It is for that several studies are focused on the search for natural anticoagulants to treat these vascular pathologies.

In this context this study was inscribed aiming-to evaluate in vitro the anticoagulant activity of the polyphenolic extracts of the leaves and fruits of a few varieties of olive Olea europaea L.

\section{Plant material}

The plant material used in our study is constituted of the leaves and fruits of four varieties of olive (Olea europea L.) : Chemlel, Sigoise, Rougette and Dathier. They were collected from Mila (station Maazouzi Lakhdar) during the month of October 2015.

\section{Methods}

We took forty leaves and fruits in a random manner for each variety. The fruits have been stoned, and then each material for extract (leaves and fruits) is placed in the oven at $40^{\circ} \mathrm{C}$ for 5 days to dry.

The dehydrated samples were triturated to obtain homogeneous samples of olive pulp pate and samples of a fine leaves powder. These last are stored in boxes, in glass, away from light and humidity, until the use for extract preparation.

\section{Extraction of polyphenols}

Having the objective to make an extraction of phenolic compounds, five grams of crushed olive leaves and fruits were added to a mixture of methanol and water $(100 \mathrm{ml}, 70: 30(\mathrm{v} / \mathrm{v}))$. The mixture was allowed to stand for 7 days at room temperature in the dark. Then, it was filtered using a $0.45 \mu \mathrm{m}$ filter (Abaza et al., 2007).

After filtration, the filtrate was evaporated using a rotavapor at a temperature of $60^{\circ} \mathrm{C}$ for a total elimination of methanol. When the solution becomes completely dry, it was retrieved with $100 \mathrm{ml}$ of a mixture of methanol and water $(70: 30(\mathrm{v} / \mathrm{v}))$ then placed in a refrigerator. 


\section{Anticoagulant activity}

The anticoagulant activity of the polyphenolic extracts of the leaves and fruits of olive was evaluated in vitro by the exogenous pathway of the coagulation on a normal plasma using a global test chronometric; the Quick time (QT).

The blood is obtained from a young adult as voluntary healthy non treaty, whose QT is normal, by venipuncture in sodium citrate $3.2 \%$ tube (9:1 v/v, blood: anticoagulant). The blood is then centrifuged for 5 minutes at $2500 \mathrm{rpm}$ to obtain platelet poor plasma.

\section{Quick time}

The prothrombin time (PT), was developed by Armand Quick in 1935 for investigating patients with liver disease (Quick, 1935). PT measures the time to form the initial clot after tissue thromboplastin is added to the recalcified, citrated blood specimen, and is an expression of the extrinsic pathway. The PT is responsive to congenital or acquired deficiencies of factors VII, X, V, and II and fibrinogen (Wiesner, 2003).

An elongated time of coagulation compared to that of witness explained that the sample exercises an anticoagulant effect in this pathway of coagulation. The effect of olive polyphenols on the exogenous pathway of coagulation has been evaluated according to the protocol described by Athukorala and his collaborators, with some changes (Athukorala et al., 2007).

On the one hand, we put $100 \mu$ l of plasma already obtained in a witness tube which is then incubated for 2 minutes at $37^{\circ} \mathrm{C}$. On the other hand, $50 \mu \mathrm{l}$ of the polyphenolic extracts diluted with distilled water to $50 \%$ $(1: 1(\mathrm{v} / \mathrm{v}))$ was added to $100 \mu \mathrm{l}$ of plasma in each of the analyze tubes, then incubated at $37^{\circ} \mathrm{C}$ during an optimal time of 15 minutes. After the incubation, thromboplastine $(200 \mu \mathrm{l})$ pre-incubated at $37^{\circ} \mathrm{C}$ for 15 minutes was added and clotting time was recorded. The results are expressed by the clotting time in second ( $\mathrm{s}$ ).

The same operation was repeated three times in the same conditions for each variety.

\section{Statistical analysis}

Statistical analyses were performed by the SPSS 21 software. The results are expressed using means $\pm_{\mathrm{s}}$ tandard deviations (SDs). Parameters were compared between groups using analysis of variance (ANOVA) and the values of $\mathrm{p} \leq 0.05$ was considered statistically significant. 


\section{Results and Discussion}

In the purpose of seeking an extension at the clotting time of which is defined by an anticoagulant activity of olive extracts, this test is performed according to the method of Athukorala et al., (2007). This classic test commonly known under the name of Prothrombin time (PT) explores the extrinsic pathway of blood coagulation where the tissue factor (thromboplastine) is the trigger of this pathway (Tripodi, 2009).

Table I: The results obtained for the anticoagulant activity (s).

\begin{tabular}{|c|c|c|c|c|}
\hline & Sigoise & Chemlel & Rougette & Dathier \\
\hline Leaves & $27,80_{* * *} \pm 1,24^{\mathrm{a}}$ & $33,51_{* * *}^{ \pm 2,04^{\mathrm{a}}}$ & $22,61_{* * *}^{ \pm 1,30^{\mathrm{a}}}$ & $20,88_{* * * *} \pm 1,24^{\mathrm{a}}$ \\
\hline Fruits & $23,49 \pm 0,53^{\mathrm{a}}$ & $32,13 \pm 1,13^{\mathrm{a}}$ & $22,05 \pm 0,13^{\mathrm{a}}$ & $24,90 \pm 1,54^{\mathrm{a}}$ \\
\hline
\end{tabular}

a: The average of the results achieved on 3 attempts \pm SD.

${ }^{* * *}$ Highly significant difference.

The analysis of these results reveals the existence of a large variability between the QT values of leaves and fruits of four varieties of olive. This is confirmed by the analysis of variance (ANOVA); it emerges a highly significant difference in the QT in the presence of the polyphenolic extracts of the leaves and fruits $(\mathrm{p}<0.001)$.

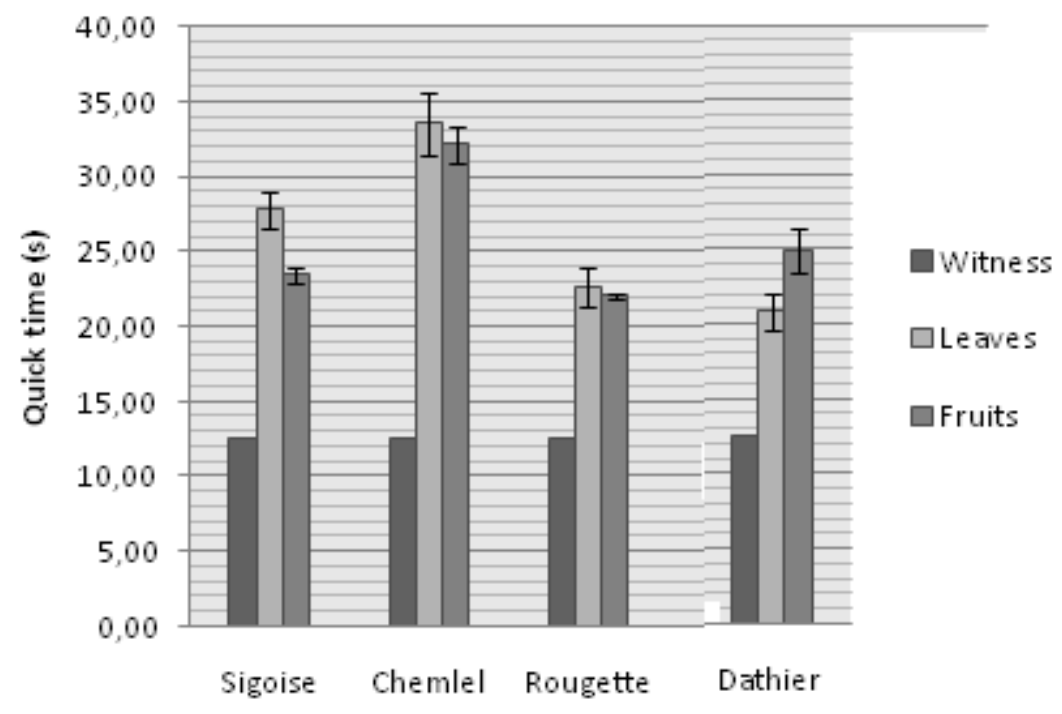

Figure $\mathbf{n}^{\circ} \mathbf{0 1}$ : The effect of the polyphenolic extracts of the leaves and fruits on the QT.

In a general way, it can be noted clearly that all the polyphenolic extracts studied exercise an anticoagulant activity. But the results show a remarkable variation of the values of this activity compared to the witness. 
In the presence of polyphenolic extracts of the leaves, we note that there is a prolongation of QT in the order of 21,01s, 15,30s, 10,11s and 8,38s in comparison to the witness (12.5 s) noted respectively among the Chemlel, Sigoise, Rougette and Dathier varieties.

In addition, in the presence of polyphenolic extracts of the fruits, it is observed that the highest prolongations of QT are among the variety Chemlel $(19,63 \mathrm{~s})$ followed by the variety Dathier (12.40 s). Then come the Sigoise and Rougette varieties by prolongations of the order of 10, $99 \mathrm{~s}$ and $9.55 \mathrm{~s}$, respectively.

By comparing the QT of the leaves and fruits extracts, we note that the anticoagulant effect of the leaves is relatively high compared to the fruits.

A similar study conducted by Manallah (2013) who has worked on the polyphenolic extracts of the fruits of two varieties of olive (Khenfas and Bouchouk) has been obtained from the results of QT slightly higher compared to our results (34.6s and $40.1 \mathrm{~s}$, respectively).

These differences between the results can be explained by the variability between the varieties examined, the reagent used, and the method of polyphenol extraction which may also be responsible for these differences.

In addition, recent studies by Lemaoui (2011) concerning the evaluation of the anticoagulant in vitro activity of the essential oils of Nigella sativa L. seeds have shown that these oils rich in polyphenols may cause a prolongation at the level of the clotting time.

\section{Conclusion}

The present work is within the framework of in vitro evaluation of the anticoagulant activity of polyphenols extracted from leaves and fruits of four varieties of olive (Olea europaea L.).

The anticoagulant activity of the polyphenolic extracts was evaluated in vitro using the Test QT who says that the polyphenols exert a great anticoagulant activity on the exogenous pathway of the coagulation with a difference very highly significant between the four varieties studied. In effect, we have noticed that the polyphenolic extracts of the leaves and fruits of the variety Chemlel present a very interesting anticoagulant capacity with a time of QT prolongation of 21,01s and $19,63 \mathrm{~s}$ in the presence of polyphenolic extracts of the leaves and fruits, respectively.

In the light of these results, it is apparent that the polyphenolic extracts of the leaves and fruits of olive can be used for the prevention of thrombosis, and as natural anticoagulants in food industries, cosmetics and pharmaceuticals. 


\section{References:}

1. Abaza L, Talorete T.P.N, Yamada P, Kurita Y, Zarrouk M et Isoda $\mathrm{H}$, 2007. Induction of Growth Inhibition and Differentiation of Human Leukemia HL-60 Cells by Tunisian Gerboui Olive Leaf Extract. Bioscience Biotechnology and Biochemistry, 71: 1306-1312.

2. AthukoralaY, Lee K.W, Kim S.K, Jeon, Y.J, 2007. Anticoagulant activity of marine green and brown algae collected from Jeju Island in Korea.Bioresource Technology, 98: 1711-1716.

3. Boskou D, 2009. Olive Oil. Minor Constituents and Health, Edition CRC Press. Boca Raton London New York, 229pp.

4. Bruneton J, 1999. Pharmacognosie: Phytochimie Plantes Médicinales. Techniques et Documentation, $3^{\text {ème }}$ Edit Lavoisier, Paris. 494pp.

5. Lemaoui A, 2011. Activités antioxydante et anticoagulante des huiles essentielles des graines de Nigellasativa L. Algérienne. Mémoire Pour l'obtention du diplôme de Magister en Biochimie. Université Ferhat Abbas, Setif. 72pp.

6. Manallah A, 2012. Activités antioxydante et anticoagulante des polyphénols de la pulpe d'olive Oleaeuropaea L. En vue de l'obtention du diplôme de Magister en biochimie appliquée. Université Ferhat Abbas, Sétif. 81pp.

7. Quick A.J, 1935. The prothrombin in hemophilia and in obstructive jaundice. J BiolChem; 109: 73-4.

8. Tripodi A, 2009.Tests of Coagulation in Liver Disease. Clinics in Liver Disease, 13: 55-61.

9. WHO, 2008. World Health Statistics 2008. 110pp.

10. Wiesner R, Edwards E, Freeman R, et al.2003. United Network for Organ Sharing Liver Disease Severity Score Committee. Model for end-stage liver disease (MELD) and allocation of donor liver. Gastroenterology; 124: 91-6. 